\title{
Exportation of Interim Order by the Arbitrator with an Approach to the Civil Procedure Code
}

\author{
Malihe Khaleghi Moghaddam ${ }^{1} \&$ Maryam Afshari ${ }^{1}$ \\ ${ }^{1}$ Department of Private Law, Damavand Branch, Islamic Azad University, Damavand, Iran \\ Correspondence: Malihe Khaleghi Moghaddam, Department of Private Law, Damavand Branch, Islamic Azad \\ University, Damavand, Iran. E-mail: khaleghimoghadamm@gmail.com
}

$\begin{array}{lc}\text { Received: May 30, } 2016 & \text { Accepted: September 16, } 2016 \quad \text { Online Published: October 30, } 2016 \\ \text { doi:10.5539/jpl.v9n9p205 } & \text { URL: http://dx.doi.org/10.5539/jpl.v9n9p205 }\end{array}$

\begin{abstract}
Arbitration is as old as human history, and disagreements between people can be resolved through arbitration thousands of years before the judicial institutions can be formed in their very primary form. Gradually communities were established growing, and it would be necessary to be approved various laws and prosperity in the field of arbitration. In this regard, Iranian legislator was discussed arbitration issue, in one of his legislative actions on April ninth of two thousand during approval of the Civil Procedure Code and in its seventh, but surprisingly in this law is not only considered notable authority to judge, but there was also silence regarding the authority interim command exportation by arbitrator. On this basis of the aforementioned attributes and aims to improve of arbitration process in the rights of Iran, we try to review and analyze authority issue interim command up to a clear possibility of issuing a temporary order by the ship's helm justice, in accordance with the provisions of our law.
\end{abstract}

Keywords: arbitrator, authorities of institution of arbitration proceedings, exportation of interim order, safeguarding measures

\section{Introduction}

According to legal and legislative history makes clear arbitration in this institution has always been the Iranian people, and factors such as prolongation of the proceedings, litigation costs and lack of freedom of communication between judge and parties were led to increase strength considering this institution in the last hundred years among jurists, and with breaking the monopoly of Justice in resolving disputes, new legal literature in our country and in legislation is created so that in paragraph 9 of the general policies of the system of judicial security one of the above mentioned policies, the use of arbitration and mediation in dispute resolution has been introduced. However, despite the importance of that arbitration, it is not above criticism, especially the lack of precision in defining the powers of arbitrator either by legislator or by the parties in the arbitration agreement is caused arbitrator withdrew from the desired path, and in some cases the parties are forced to repeat the claim in court. One of the key factors deviation legislative silence is on explicit granting some of the authority to the arbitrator. In this description can be analyzed with this optional; at the same time expanding the scope of influence of this institution in the judicial system of the country in the past few decades have been avoided a repeat of the damage, and at the same time helped to the judicial precedents in arbitration. Our efforts in this article are that authority subject of arbitrator in issuing the interim order with regard to the provisions of The Civil Procedure Act has been studied and analyzed.

\section{The First Chapter: Concept and Conditions of Interim Order}

Interim order in the dictionary is: "kind of court ruling that face which indicates the act, omission or seizure of property". Despite the provisions of the former Civil Procedure and the new Code of Civil Procedure, a definition of interim order has been done, some so-called scholars have defined it this way: "interim order is a legal entity that according to the applicant in some cases that require urgent task, and demand is related to the original case, deposit of probable damages and legal arrangements to comply with the request of the competent court will be decided the interim". In other words: "Interim orders are precautionary measures to prevent the entry of irreparable damages that may be arised due to the length of the arbitration process, and to seize goods, perform or refrain from doing something by reference to the nature of the proceedings taken care of without entering". This way of handling is different from with normal handling, and is renowned for an immediate trial 
which has its own characteristics. One of the things I demand an interim order issued by resorting to it in order to ensure that parties can be somehow grown to know their rights and take steps. Legislator in the Civil Procedure Code to issue an interim order situation is predicted that these conditions are as follows:

\subsection{First Speech: The Applicant's Interest Stakeholders}

According to Article 310 of the Civil Procedure Code the court only at the request of the beneficiary, the interim order is exported. In fact, one of the general conditions required for each request, the applicant's beneficiary and having the legal capacity or if the applicant is established, otherwise, the court is exported reject of the request. For this reason, it seems arbitrator as one of the general conditions necessary to accept any request should be considered the requesting and noble beneficiary, and if the request is accepted that he proved to be the case with arguments. So if court or arbitration issue urgently acquire it, the beneficiary is requested to issue it cannot be exported it directly.

\subsection{Second Speech: The Urgency of Issuing the Interim Order}

In most cases, the interim order is an institution that fights the urge and desire beneficiary; but since the issuance and enforcement to the party against whom has been issued create a great difficulties; it must be issued in cases that this is of urgent matters, and decide about it is urgent. So the main challenge of the lack legal criterion for perceptions is "Urgency", and the reason of the absence of such a measure is presence of entente votes on this issue is published. Nevertheless, it is a matter of urgency that its diagnosis in the absence of a precise measure under Article 315 of the Code of Civil Procedure has been left to the discretion of the investigating authority.

\subsection{Third Speech: Obtaining a Supply from the Applicant}

The Court cannot be provided without obtaining the right of the applicant to issue interim orders and the obvious differences of Civil Procedure Act 1318 is the law 2000 that current the beneficiary in obtaining interim order is required by law to provide suitable deliver, and even in that case persons stipulated in the rule of law are exempted from payment of litigation costs including the Foundation exempt from payment of interim order will not be provided; and the degree of solvency and the of beneficiaries will have no effect on the obtaining of security, and application of Article 319 of Civil Procedure Code also reflects this RA. Of course, if the legislator has diagnosis in supplying with potential damage, has been put responsible for the reference of the tendentious, and Its reference in the same way, according to the experts in determining the urgency required to issue temporary orders can provide in determining suitability and adequacy acclaimed a use expert opinion.

\section{Chapter II: Arbitrator'S Authority in Issuance of the Interim Order}

Chapter VII of the Civil Procedure Code Iran, which in turn is responsible for domestic arbitration rules, there is no regulation of evidence provided arbitrator issuance of the interim order. Accordingly reviews have arbitrator in this controversial issue is the need to scrutinize and review comments filed in this regard. However, due to the silence of the legislator in granting or denial of such authority of arbitrator, lawyers close less to the subject and explore it. And in most cases only mentioned in the writings of the great legislator can be seen passing to silence etc; and in terms of comment on the background is difficult. However, the attempt is that according to the criteria of legal and theoretical reasons, explore and analyze the issue.

\subsection{First Speech: Comments on the Disposal of Arbitrator to Issue Interim Order}

At the discretion of arbitrator to issue interim order pursuant to Code of Civil Procedure, states: "Although the legislator reaction in formulation and regulation of arbitration in the arbitration institution in relation to the jurisdiction of interim order has been silent, and according to the principle of universal jurisdiction in the judgment under Code of Civil Procedure ordering the jurisdiction of the court is only temporary. The basis is on the lack of it in case of doubt on the competence of arbitrator and arbitrators". Others believe it is: "Since the interim order as an immediate hearing process is exceptional and scope of the exception cannot be extended, there is no reason to arbitrator interim order issued by the Civil Procedure Code", but one of the masters law argues that the lack of proper insertion as the referee's authority, but one of the law professor believes that failure to explicit inserted this authority for arbitrator is as that arbitrator cannot export interim order. The implementation of the injunction exported to the referee's confession supply. With serious problems, but Article 477 of the Code of Civil Procedure which arbitrator is required to apply the rules on arbitration among the provisions mentioned in the arbitration agreement, it suggests that the parties can consent to each competent to issue such an order will be arbitrator granted. So as the mutual consent of the parties in the authorization to a third party arbitrator to resolve differences vote is valid, in the parties consent to grant authority to issue orders, it is not seen as an obstacle. If the arbitration agreement involves such option, arbitrator is required to compliance. In fact, arbitration is institutional contract, and wills been have been created the institution can be 
rejected or approve issuance of the interim order by arbitrator; and in general temporary order issued by the arbitrator is a symbol of respect for the will of the parties to arbitration that the product of principle of sovereignty is will. So the effect of interim order has urgent nature compared to parties as effect of contract in the light of the principle of relativity and the need to will be checked. Due to the principle stated this question is raised that issuance of the command what will be required for third party, and will third-party requiring acceptance of the interim order be arbitrator? The answer to this question the binding force of awards and powers of persuasion depends on it because arbitration award is enforceable by judicial authority administrative organizations, and the interim order is no exception of this. As a result, arbitrator's competence in internal arbitration to issue a temporary order based on the application of these rules depends on the mutual consent of the parties, but for talking and conclusion decisively according to the legislative and judicial bodies on the arbitrator's competence of the Civil Procedure Code in relation to the issuance of the interim order, we have to wait and see what position on the arbitrator's competence for ordering and corrective measures will be taken and to what extent it will be important empathy. Although in this case with regard to Article 477 of the Code of Civil Procedure, in which approved after the hearing and verdict are not subject to the formalities of Civil Procedure; and in fact the philosophy of arbitration to resolve the animosity between the parties is as it seems that arbitrators will not have authority on issuing the interim order, but the delay consideration of this matter states that arbitrator at the trial must obey the rules of arbitration, another attitude towards this issue creates.

In fact, the term "arbitration Subject to the provisions" in the above article is 454 to 501 of the Public and Revolutionary Court Hearing Procedures in civil matters as well as the authority of the conflicting parties pursuant to the arbitration agreement or even orally to the referee have including authority to issue temporary orders; in fact, although the Civil Procedure Code does not have explicitly regarding the issuance of interim order by arbitrator, but considering that there is strong reason to ban it. Especially after recourse to arbitration, undoubtedly the intention of the parties is determine of the ultimate solution and is essential to end dispute, and is plan of same lawsuit against agreement of the parties, and is faced with the objection of respondent by the magistrate with the lack audition the dispute. If the parties have also arbitrator to be merely on the nature of the handle, or has a broader authorities to remain silent, their intension is that arbitrator pay attention to the nature of the dispute. However, this is not umbilical of this topic that every time the parties want, they are able to give will to comment on personal and suppliers affairs, and is exported partial or total vote on this field that in these cases, competence of the Court give its place to the arbitrator's competence to export in the immediate subject of vote by arbitrator that like other arbitration award by resorting to the power of the court, it can be carried or canceled, as well as the rules which applied in relation to grant or denial of authority to the temporary and safeguarding measures have remained silent, this silence can be interpreted implied powers to arbitrator or the arbitral tribunal. To better interpret in a place where rules or the law applicable to the arbitration, not arbitrarily applied to the arbitrator gives temporary safeguarding measures, and expressly disclaims is not authorized. It seems that the arbitral tribunal or arbitrator have inherent authority to carry out such actions. However, when the parties are referred solve of their disputes to arbitration, he has the authority to impose any necessary measures to resolve disputes that the authority includes the temporary corrective measures to ensure the rights of the parties and the efficiency of the final decision of arbitration is necessary.

The result can be believed, arbitrator can request one of the parties or if the parties pursuant to the arbitration agreements, it is optional to have arbitrator, interim order is issued because in the public international law arbitrator issued interim order of authority inherent in dealing with differences has been considered, it means that arbitration is the basis of mutual consent of the parties, and domestic and international law is confirmed solely on it, and is one of the components of this voluntary agreement arbitrator to issue an injunction and the decision on safeguarding measures. That is why in absolute terms will not be needed for intervention and institutional any reference to the special court issued a temporary order and safeguarding measures.

Of course, the idea that there is full independence for arbitration institution; it seems objectionable because in practice and in the many cases had been referred to arbitration proceedings will not be resolved without court intervention, and the decision will not be implemented without support of arbitrator's court, but if we interpret the views of this group and in this way that the parties to the conflict to arbitration with the consent of arbitrator, while their satisfaction have been announced. Therefore, in the subjects that arbitrator has no explicit authority, but frustration of having such powers can be prevented in the end he could take his main task, arbitrator is allowed to invoke its inherent authority and refer to it. The exportation of temporary order is necessary in cases that have been requested by the beneficiary. Arbitrator refused to take timely action may result in the violation of the rights of one of the parties or under recognizing the urgency of the matter with the referee; ne the principle is referred to arbitration; and referring to arbitration makes impossible. 
As a result, it should be allowed to be the issuance of the interim order of items that can be inherent to arbitrator or the arbitral tribunal is to be made available, and the authority of international law inherent arbitrator has no special features that it cannot be generalized to the arbitration provisions in domestic law and to domestic arbitration authority, especially in view of the silence Code of Civil Procedure. But 477 Article the Civil Procedure Code which has stated after the investigation and decision is not subject to the provisions of Civil Procedure, this does not mean that deceased may challenge to any type and in any manner to export orders, and put name on it as interim order because the command does not have sufficient funds to run through law enforcement. So arbitrator export a temporary order should such interim order issued by the court in matters which are issued urgently, and that Article 315 of the Civil Procedure Code has made recognizing the urgency of the matter the court. At the request in writing and verbally that after the interim order is issued after the issuance of the interim order. So recognizing the urgency of the matter will be with the arbitrator, and the arbitrator is considered to the diagnosis of "urgency" in addition to all the evidences of the parties and ability to proof, in addition to the necessary expertise, local search, can be also examined the location and use witness testimony, but it cannot reduced to be sure that such actions should be carried out are not incompatible with the concept of urgency. Even it seems as the Court has been required pursuant to 319, appropriate security was allowed to the issuance of the interim order, and at this stage as well appropriate recognition of providing is on the responsibility of the court, and if necessary, magistrate can use of the view of the expert if negate of urgency is not the matter. And to guarantee the rights of the other party, the wisdom and the fairness of the applicant should be issued a temporary order to obtain an appropriate guarantee, and in order to Providing a proper diagnosis from any device that is necessary and legal including expert opinion is used (if negate is not urgently necessary to issue an interim order). And if the applicant refuses to provide payment, arbitrator is also refrained from issuing such order arbitration.

\subsection{Second Speech: Conditions for Issuing Temporary Order by Arbitrator}

Now that with the arguments and opinions raised, this concluded that arbitrator in accordance with internal regulations and the Civil Procedure Code has the power to impose temporary order. Questions will be created in the mind that cannot release them without response, and it is necessary to analyze each of them with the relevant legal provisions appropriate response is given, including: when may be raised application for issuance of the interim order of arbitrator. Is it necessary to address as the court for consideration and issuance of temporary order of investigation session is formed? is the judge issue an injunction rejected, and is the judge may issue an injunction rejected? Will mentioned question be required to pay? Is mentioned request necessary to pay a fee? Implementation of the interim order issued by the arbitrator how and on what authority will be responsible? Whether its implementation would require approval from the head of jurisdiction? If necessary the judge may order the temporary effect of the cancellation or fix it? Is the property of the deceased may arbitrator the effectiveness of security fixes?

By virtue Article 312 of the Code of Civil Procedure injunction from the court before or after litigated and litigated is done. Considering the manner in which the arbitration proceedings take place, and since the true nature of the judgment is that first, the parties refer to the consent judgment, and then is referred to arbitrator. If the arbitrator can initiate proceedings, arbitration has been accepted that there are several modes:

1) First mode: The parties pursuant to Article 455 of the Civil Procedure Code have accepted while the transaction before the event of any discrepancies. If the difference between them erupted to refer to arbitration, and based on the first part of Article 458 of the law has been determined before the arbitrator or arbitrators of their dispute, have been received their acceptance. In this case, it seems from the arbitration referred to earlier or in other words before the original class action suit filed request for the issuance of temporary orders, in this case, there is a contrary view. Based on that arbitrator has right of investigation and issuance of vote only after the Court of Arbitration. Therefore, in situations where the arbitral tribunal has not been constituted, he does not have the authority to issue orders. It should be noted the Court of Arbitration is more common in international law, and internal arbitration normally is not common to speak of the formation of the arbitral tribunal, and by selecting the referee and receiving the acceptance of the adjudicatory authority is given to him. So it seems that in this case arbitrator if the arbitrator is accepted, it can be issued temporary orders to act.

2) Second and third mode: Agreement parties have been signed referred to arbitration, but choose of judges have postponed after the outbreak of the conflict, or the parties after a dispute mutual consent decide, is referred to arbitration. However, the arbitrator or arbitrators have identified, in this case, it seems, contrary to the implications of Article 311 and 318 Code of Civil Procedure, application for issuance of the interim order of the court even before litigation, it is also possible not to exist the possibility to request the issuance of such an order from arbitrator in both the above cases, and it seems as the judges under article 477 of the Code of Civil 
Procedure in the proceedings and the judgment subject to the provisions of Civil Procedure do not address the special procedures, the parties are also required to comply with it, and in case arbitration is not required for the issuance of the interim order on a petition filed papers to be. But if the arbitration agreement is not an agreement that arbitration for the enterprise, for example by the arbitration Chamber of Commerce, Industries and mines is carried out, it should be respected rules of that organization in any request that the authorities will be judged, and if the Arbitration is for certain conditions to apply for the forecast, the applicant must comply with the required conditions to arbitration on the basis of regulations allowing the aforementioned find for ordering.

Article 314 stipulates that: "To address affairs immediate, convenient hours and day are determined by the court and the parties invited to the court. In situations that urgency of our task is appropriateness. It can be used without an appointment and invite parties and even in times affairs trial sites have been shut down or otherwise be addressed." In relation to whether should the jury be formed a meeting to address urgent affairs? It has been expressed what has been anticipated in mentioned matter of the court, if urgency is got to the extent of the appropriateness, and is at the discretion of the court that way of investigation is run the other way, and in practice usually only in cases where the court according to the provisions of the request and evidence submitted in the course of issuing the interim order, the order of appointment and invite the parties are exported, otherwise, in most cases without meeting decides to issue the injunction.

On this basis and in accordance with the Code of Civil Procedure expressly provide for arbitrator issuing the interim order has not been anticipated. It seems the jury for consideration and decision making in relation to the issuance of the interim order, will not be required to convene to deal with urgent affairs, and it can be with or without forming a meeting make a decision $\mathrm{n}$ this regard, unless the parties have agreed otherwise in the contract Arbitration. Of course absentia issued and the implementation of the interim order has usually criticized because in the arbitration systems, arbitrator takes his powers of the arbitration agreements, and the principle of correspondence in the arbitration over court proceedings is concerned, and the arbitrator has important moral duty to abide by this principle in relation to both parties, this means that he cannot be addressed without notice enter any of the parties. While often an important part of safeguarding and temporary appointments to be implemented, and the necessary power have for an unexpected, is issued and run without informing the other party and in absentia that the issue is in contradiction with the principle of correspondence. As a result, it is believed that deviate of the principle of correspondence in the arbitration system, even international commercial arbitration is impossible, unless specified has been there. Thus, provisions of Article 320 are Code of Civil Procedure for the courts, and it is only executable if the particular circumstances of urgency are requested, but we can say in response to this criticism, if we want to know so bound to observe the principle of correspondence in arbitration, we'll forget that under article 1 of the Law of Civil Procedure also magistrate is obliged to observe all principles of due process, is including correspondence principle. Otherwise, the enforcement for this provision is based on paragraph 3 of Article 371 ruling issued in violation of the Code of Civil Procedure because the legislature has expressly prescribed the drug in Article 320 that the court also work in urgent situations, can be issued a temporary order without informing the other party before the notification is run.

In relation to the third question must be said that as the Court cannot accept the interim order, and although the court's decision to reject the request to explicitly "arrangement" has not been applicable, but in practice, the courts have issued denials this case, the drug as well as the court after investigating the circumstances (urgency and the applicant's interest, etc.) cannot be accepted request for temporary order, and is rejected it; and in the same way that we cannot approve or reject submissions the issued request by the court independently appeal or not appeal, it seems that the interim order issued by the arbitral have the same conditions, except in two cases. The first case organizational practices followed in the light of the parties to the arbitration and the arbitration rules of the organization, and have been Independent complaints authority with respect to this topic that is the organization itself, and is body for the examination of protest. Arbitration is pursued organizational practices to organizational practices, and the parties in the light of the provisions of the judging organization have been independent complaints authority with respect to this topic that organization is placed as body for the examination protest.

The second case; the parties have been predicted the authority to investigate to the protest by virtue arbitral agreement for arbitrator. In this case, the arbitrator will be able to make these options, have been investigated to the protest, and if arbitrator does not want, or for any reason or assignment of authority and refuses to running multiple to quit that has been on him by virtue responsible for arbitration agreement. The parties have the right to go to the court, there will be the referee formal investigation into the rigging. Of course, it is approved, even if the arbitrator has the right to address this protest, able to handle the kind of appeal and the appeal will be called the Code of Civil Procedure, because no references other than the aforementioned references in the law to deal 
with complaints of this type will not have, and even if with these titles are logged in hear and decide, adopted vote does not have the necessary legal validity that is found ability to run according to Article 28 of the law civil law enforcement in the event of closing. In other words, what will be done, the same appeal and the appeal is not known and conventional such arbitration agreements unless the parties have established a name on it.

Answer to the fourth question is also certainly involved investigating various forms. 1. If the arbitration to the organizational practices is continued. In these circumstances, if the organization has been predicted, the applicant must pay the costs involved to meet the requirements of the Regulation for the organization to advance the goals and establish their rights to use. 2: In the arbitration in charge of the case if the applicant is shown, and or the Article 500 of the Civil Procedure Code in the relationship between the jury and the parties by mutual consent of the process of obtaining faceted have been made, it is the responsibility of the parties that is acted to the mutual agreements to have right to demand commitment. 3. In accordance with the provisions arbitration made by arbitrators appointed by the court or arbitration is done according to certain rules, as compulsory arbitration under Articles 36 and 37 of the Securities Market Law adopted by the Islamic Republic of Iran in 1384; since the law expressly vested by the referee to issue a temporary order has not been determined. Commenting on the fees necessary to issue interim order in the same way that Clause 2, Article 325 of Code of Civil Procedure has been determined, simply it will not be possible, and needs more scrutiny and review, and it seems since this theme will be added additional duty to parties, cannot be provided mentioned note of broad interpretation, is imposed pay this fee on order applicant, however, the opposite view is also notable In the this regard.

In the relation to the question that interim order issued by the arbitrator or orders or payment of an appropriate guarantee by the referee how and by what arbitrator will be implemented; it can be said in the institutional arbitration as the organization may be predicted the possibility of applying, issuing conditions, the time of application or fee required for request, it may be provided conditions necessary for the implementation of the arbitration award, including interim injunction issued by him. But in the mandatory, case and optional arbitrations can be attached to the license and authority to issue interim orders by arbitrator. In the same way can also be accepted if the verdict by the referees with other legal requirements is necessary, according to Article 28 of the law implementation of the civil laws will be carried out, about whether the implementation of the interim order of arbitrator is required approval from the head of jurisdiction, first, it is necessary that is considered philosophy of judicial appointments confirmed by the head of the interim order issued by arbitrator.

Predict of what is in the clause 1 of Article 325 of the Code of Civil Procedure, it is considered obvious in the year 2001, and apparently insert such a regulations in the new law has to compensate for the shortcomings in the law. The first flaw is caused that unlike the previous law, in current law does not reject or accept interim injunction subject to revision. Secondly, under the current law judges are allowed to export interim order if in the old law only under Article 773 judges that had special notification, could be cared request for temporary order since that assumes the legislator was that only some judges have the expertise necessary to address the urgent affairs.

Now, according to the legislator to insert such regulations it seems since arbitration of the enforcement is suspended governance. Normally, orders and appointments arbitrator is required public powers, the role of executive oversight and support of the court, and would not be farfetched logic that implementation of Interim order issued by the arbitrator in domestic arbitration is also required approval from the head of jurisdiction.

As stated in the conditions for issuing temporary order, now and in accordance with current law in case the court has been authorized to issue temporary orders that from applicant will be obtained the appropriate security, therefore, if we put on it that the jury has the power to impose such an order to the wisdom, fairness and justice should be like the court to protect the interests and rights of the other party, the applicant will obtain an appropriate guarantee, and would be unlikely that in necessary conditions and by virtue the same causes and reasons that the referee is authorized to issue temporary orders or obtaining of security in front of it, and have had the right to issue orders to cancel it, issuing orders of elimination of the effect of it or issuing orders removal of effect of adopted provision. In conjunction with this description; removal of seizure of property or removal of effect of Interim order, in case is with arbitrator that time of arbitration is still is still remained, and the arbitrator can intervene in this case, obviously arbitrator due to the lack of optional power does not have the possibility of intervention, and the court is acting in his place, and in this case the court's decision is certain. At the end of this discussion in conjunction with Article 318 Code of Civil Procedure must be stated, court along tribunal can be exported interim order and security as well as garnishment in such a case, how can be stipulated that within the period in articles 112 and 318 of the Code of Civil Procedure of demanding can be initiate criminal proceedings if the agreement have been to refer to arbitration? In this regard, one of the professors believe that: "Issuing garnishment and the interim order within the competence of the" court " is which has competent to investigate to 
the principle of dispute, so if there is arbitration agreement and accept to the arbitrator; obtaining financing and interim orders in domestic arbitration, both the Court and the arbitrator is impossible. ", and in the weekly meetings of judges of martyr Beheshti Judicial Complex on November 8, 2010 and November 15, 2010. In analyzing this issue if there is arbitration agreement, the court has authorized to issue interim orders or not? According to the situation and the urgency of the matter, equally a group of judges was announced the request as audible by the court and another group as inaudible. It has also stated in another comment: "even if you cannot complete something, do not leave it completely" Here it should be based on the principles of cautious, and in this case it is necessary authorities to collect the judgment and the court. Because in fact the legislator of this article, necessity of action is in the nature of the dispute not that in the above-mentioned deadlines, litigate is performed just in court".

In our opinion, this last argument has more consistent and more acceptable with equity verdict, in spite of efforts that have been done to ensure the autonomy of judgment of the Court, and to act to self-contained and independent by arbitrator, the fact is that authorities of power arbitration and authority to govern are not similar to authority and power of the courts. References of arbitration are required assistance and direct intervention of the court especially in the case of arbitration, sometimes even for managing the flow of arbitration, such as installing the referee for failing party and court intervention in the enforcement of an arbitration award. As a result, the effectiveness of the arbitration award to a wide extent is dependent on the cooperation and support particularly, in the context of the interim order of the court and safeguarding measures against it, and adjustment of the cooperation methods and its various manifestations is subordinate the internal law, the place of arbitration or the law of the place of vote enforcement. As well as administrative obstacles that are in implementation of the interim order issued by the judges, in practice are caused to be faced with little luck issuance of interim order by the Institution of Arbitration Proceedings. Although trend of thought to accept the authority of the referee to issue such an order exists, but usually the parties of arbitration prefer to demand of court issuance of temporary appointments to avoid the constraints and obstacles in its implementation However, many scientific hints about the interim order by the judges are unknown that judicial procedures should decide on it.

\section{Conclusion}

Arbitration has remarkable experience and benefits, in recent years, it could be considered, and this choice is increasingly expanding, and that choice is increasingly expanding. A key principle of any arbitration is that has several authorities during the arbitration, and the arbitrator takes his authorities from two sources arbitration agreements and arbitration law of the place, and with the benefit of them is trying to properly handle, and is exported proper vote. Regarding the authorization interim issuing orders by referee or an arbitral tribunal with an emphasis on the provisions of Chapter VII of the Civil Procedure can be said: Although in the mentioned provisions, there are not any regulations that are indicative on the arbitrator or arbitrators authority to issue interim order. Lack of interpolation authority of exportation interim order by arbitrator in the said law constitutes that at the moment arbitrator cannot export interim order, but Article 477 of the Code of Civil Procedure that arbitrator is required to apply the rules on arbitration provisions of the arbitration agreement. Accordingly, if the parties mutual consent, each competent to issue such an order is granted to arbitrator, no doubt will be left that arbitrator has authority. And if that is the option arbitration agreement involves arbitrator is obliged to follow, of course competence of arbitrators in the civil arbitrations to issue interim order based on the application of these rules is depended on mutual consent of the parties. Also, in cases in which the parties do not give such authority to arbitrator, considering that there is no a strong reason to ban it, if the parties are handled towards the arbitrator should merely in the nature of it, or has a broader authority remain silent. Their intention is that the arbitrator is ended handling properly, and is exported fair vote and on the nature of the dispute that of course in such a case is not contraindicated, the arbitrator is performed to export appropriate vote in the nature of the dispute in case circumstances are dictated to issue interim order.

\section{References}

Abdullah, K. (2015). arbitration and claims its rights in the judicial procedure (3rd ed.). Tehran: Publishing Company, p. 226.

Afshar, S., \& Mohsen, S. (1994). civil procedure and commercial (2nd ed.). Tehran University Jihad Institute Majed Press, p. 233.

Beheshti, M. J., \& Mardani, N. (2011). civil procedure (Vol. II, 2nd ed.). Tehran: Publication of Mizan, p. 126.

Craig, G. (2000). park and paulsson, International Chamber of Commerce Arbitation (3rd ed.). Occean publication, p 416. 
Hemmat Kar, H. (2002, Spring). Exportation interim order and security by the referee. Strategic Management Research Quarterly, 52-53.

Jaafari Langroodi, M. J. (2010). terminology rights (21st ed.). Tehran: Ganj Danesh press, p. 290.

Mohebi, M. (2013). safeguarding measures in international commercial arbitration (UNCITRAL Arbitration Rules modified) Conference of the centennial of the establishment of the Institution of Arbitration Proceedings on rights in Iran, Tehran: Institute for Studies and Legal preceding studies of Knowledge, Third Edition, p. 150.

Moslehi, J. (2006, Winter and fall). about the national court intervention in arbitration process. Public Law Research Quarterly, 265.

Nikbakht, H. R. (2012). international commercial arbitration (arbitration procedure) (2nd ed.). Tehran: Institute of Business Studies and Research, p. 264.

Piran, H. (2013). "interim order in international arbitration" of the centennial of the establishment of the Institution of Arbitration Proceedings on the Rights Conference, Tehran: Institute for Studies and Legal preceding studies of Knowledge, Third Edition, p. 252.

Shams, A. (2014). civil procedure (advanced course) (Vol. III, 30th ed.). Tehran: Drake press, p. 389.

Survey, M. B. (2011). applied approach to the issue of arbitration in Iran (2nd ed.). Tehran: Tehran University Press, p. 24.

Vahedi, Q. (2008). civil procedure (Vol. II, 4th ed.). Tehran: Legal Foundation amount, p. 146.

ZadehMorteza, Y. (2015). arbitration procedures (2nd ed.). Tehran: Publishing Corporation, p. 157.

\section{Copyrights}

Copyright for this article is retained by the author(s), with first publication rights granted to the journal.

This is an open-access article distributed under the terms and conditions of the Creative Commons Attribution license (http://creativecommons.org/licenses/by/4.0/). 